\title{
Serbia's National Security Strategy - from where, through what and where to go
}

\begin{abstract}
Abstrakt
Strategia Bezpieczeństwa Narodowego jest jednym z krytycznych dokumentów państwa, sublimującym wiedzę o bezpieczeństwie, możliwych formach zagrożenia oraz proponowanych wytycznych dla zapewnienia bezpieczeństwa państwa. Dynamiczne procesy w geopolitycznym środowisku globalnym i regionalnym, globalizacja form i treści możliwych naruszeń bezpieczeństwa, ciągły wyścig zbrojeń oraz zmieniona fizjonomia wojny są dominującymi wektorami wpływu na strategię bezpieczeństwa narodowego każdego państwa. W 2019 r. Republika Serbii przyjęła swoją najnowszą Strategię Bezpieczeństwa Narodowego.

Artykuł analizuje deklarowane determinanty polityki zagranicznej w strategiach bezpieczeństwa narodowego Serbii, z zamiarem ich krytycznego przeciwstawienia aktualnym zagrożeniom dla bezpieczeństwa narodowego kraju. Bazując na metodzie porównawczej i analizie aktualnych dokumentów, z uwzględnieniem realiów politycznych i gospodarczych, w artykule porównuje się zaproponowane priorytety wraz z możliwymi tendencjami rozwojowymi, z poszanowaniem wpływu podmiotów wewnętrznych i zewnętrznych na rozwój systemu bezpieczeństwa narodowego i stanu Republiki Serbii. Artykuł krytycznie bada deklarowane determinanty polityki zagranicznej w narodowych strategiach bezpieczeństwa Serbii poprzez analizę aktualnych dokumentów i metod porównawczych.
\end{abstract}

Słowa kluczowe: bezpieczeństwo narodowe, Republika Serbii, soft power, komunikacja strategiczna, tożsamość narodowa

\section{The overall frame of Serbia's contemporary national security}

The current geopolitical scene is characterized by complexity and changes in content, forms, and actors. In the post-Cold War period, globalization has had a decisive influence on understanding international relations. Areas of social life 
that are the drivers, and at the same time the endpoint of any global activity, are the international economy and politics. Changes in relations in these areas fundamentally affect the change in the international order. In the first decades of the 21st century, international politics has been marked by many antagonisms that pose threats to global and regional security. The spatial irrelevance of global security threats, which transcend states' borders and military-political alliances, has been expressed. The trend of global security challenges relates to dramatic environmental disruption, economic shocks and disproportions, social inequalities and antagonisms, abuses of technology, and geopolitically confronted interests ${ }^{1}$.

The relativization of international law and states' sovereignty also contributes to the world's increase in insecurity ${ }^{2}$. This conditions the rise of ethnic and religious tensions, separatism ${ }^{3}$, radical Islamism ${ }^{4}$, violent extremism ${ }^{5}$, bidding for control of natural resources ${ }^{6}$, interventionism ${ }^{7}$, terrorism and organized crime $^{8}$, the proliferation of weapons of mass destruction, threats to information security ${ }^{9}$, illegal mass migrations, and hybrid threats ${ }^{10}$.

We witness that the virus Covid 19 pandemic almost stopped planet life, causing unpredictable consequences. The current pandemic will certainly deepen geopolitical antagonisms and open numerous crises, especially in the economy. At the same time, the geopolitical competition of the unipolar and multipolar concept of international politics continues. This complex and multidimensional

1 M. Mitrovic, Influence of global security environment on collective security and defence science, „Security and Defence Quarterly” 2019, Vol. 24, No. 2, p. 5-20, https://doi.org/10.35467/ sdq/106088.

2 N.M. Ripsman, T.V. Paul, Globalization and the National Security State, Oxford 2010.

3 D. Rutledge, D. Kimya, The Wiley Blackwell Encyclopedia of Race, Ethnicity, and Nationalism, Separatism, (online) 2015, DOI: 10.1002/9781118663202.wberen192.

4 C. Cemgil, The international order and the persistence of 'violent extremism' in the Islamic world, „Philosophy and Social Criticism” 2017, Vol. 43(4-5), pp. 529-538, https://doi.org/10. 1177/0191453716682371.

5 H. Mirahmadi, Building Resilience against Violent Extremism: A Community - Based Approach, „ANNALS AAPSS” 2016, No. 668, pp. 129-144, DOI: 10.1177/0002716216671303.

6 J. Colgan, Fueling the Fire: Pathways from Oil to War, „International Security” 2013, No. 38 (2), p. $147-180$.

7 S. Mijalković, G. Milošević, Korelacija ekonomske, korporativne i nacionalne bezbednosti, „Megatrend revija” 2011, Vol. 8 (2), s. 479-496.

8 B. Teofilović, T. Teofilović, N. Teofilović, Sprega terorizma i organizovanog kriminala kao bezbednosni rizik, „Pravne teme” 2016, Godina 4, Broj 8, s. 171-181.

9 J. Phahlamohlaka, Globalisation, and national security issues for the state: implications for national ICT policies, [in:] eds. C. Avgerou, M.L. Smith, P. van den Besselaar, Social Dimensions of Information and Communication Technology Policy, „IFIP Processing” 2008, Vol. 282, p. $95-107$.

10 M. Mitrovic, Savremeni izazovi upravljanja nacionalnom bezbednošću u hibridnom bezbednosnom okruženju, „Zbornik radova Međunarodne naučne konferencije EMAN 2017”, Ljubljana 2017, s. 716-721. 
conflict that significantly affects global security is read through the United States, Russia, and China's actions. Simultaneously, as the bearer of unipolarity, the United States strives to maintain the capitalized advantage of victory in the Cold War. On the other hand, as proponents of the multipolar concept of the world's functioning, China and Russia are trying to initiate a process of significant reconstruction of international relations to change the balance of power in the world ${ }^{11}$.

The European Union is preoccupied with internal challenges of an economic, social, and political nature. Thus, it can less effectively promote its integrative capacities $^{12}$. The European continent's burning crisis is on its doorstep - the annexation of Crimea and the uprising and secession of the eastern parts of Ukraine. The Minsk agreement created essential opportunities for resolving this crisis. However, the space of Ukraine in economic, energy, infrastructural, and spatial sense, directly and indirectly, affects many geopolitical and strategic issues of Europe, Russia, the Black Sea region, and the Middle East ${ }^{13}$. Furthermore, the war in Syria and its complex structure and the interaction of the parties' diverse interests to the conflict represent one of the burning conflicts on the European continent's threshold ${ }^{14}$.

In the Balkans, where Central Europe, Eurasia, the Atlantic, and the Islamic world's strategic interests intersect, regional countries face many complex security challenges. The scope of European integration has shown a changing direction in the security consolidation of that area, and the different geopolitical aspirations of the great and regional powers further complicate the Balkan security milieu. The most substantial security challenges remain due to SFR Yugoslavia's disintegration and the NATO intervention against Yugoslavia in 1999. The unresolved status of Kosovo and Metohija $(\mathrm{KaM})^{15}$ is the dominant source of instability in the region, generating many security problems. This area under an international

11 D. Jevtić, M. Talijan, A. Dumić, Geopolitičke promene i prekompozicije u globalnim odnosima, „Vojno delo” 2018, Vol. 70, br. 2, s. 25-39, DOI: 10.5937/vojdelo1802025J.

12 M. Matthijs, Lessons and learnings from a decade of EU crises, „Journal of European Public Policy" 2020, 27:8, p. 1127-1136, DOI: 10.1080/13501763.2020.1787489.

13 L.F. Stephen, S. Pezard, A. Radin, N. Chandler, K. Crane, T.S. Szayna, Russia and the West After the Ukrainian Crisis: European Vulnerabilities to Russian Pressures, Santa Monica 2017. M. Baltes, Causes and Consequences of the Syrian Civil War, Senior Theses 2016.

15 Kosovo and Metohija is the southern autonomy region of the Republic of Serbia, shortly called Kosovo, which self-declared independence in 2008. OUN does not recognize Kosovo as an independent state. The number of states which recognize Kosovo as an independent state is between 106 and 114. Kosovo's status is defined by Resolution 1244 of OUN, and the territory is under observation and the protective presence of OUN and the EU with a strong presence of armed forces, police, and administrative staff from the international community. Kosovo has a parliamentary system of governance, with the president as an elected leader. All references to Kosovo, whether to the territory, institution, or population, in this text should not be prejudged and be understood in full compliance with United Nations Security Council Resolution 1244. 
protectorate is essentially an unfinished state with weak institutions. Drug trafficking, recruitment, and return of terrorists from Syria, systemic corruption are security problems are dominant in this area. The Republic of Serbia does not accept the unilaterally declared independence of its southern province. Still, it is ready to, with the European Union and other international actors' mediation, seek a compromise solution with the Albanian people's representatives in Kosovo. However, the strengthening of extreme nationalism and the permanent promotion of the "Great Albania" project ${ }^{16}$, as well as Prishtina's unwillingness to comply with the provisions of the signatories, especially the Brussels Agreement, represent a serious obstacle to reaching a final and long-term sustainable agreement ${ }^{17}$.

The instability of the region is also caused by Bosnia and Herzegovina's political situation, implying severe state institutions' functional problems. Attempts to revise the Dayton Agreement, as well as the permanent manipulation of war victims to shift individual guilt of war crimes to collectivities, are undermining the already fragile trust among the constituent peoples, which further slows down the reconciliation process, not only within Bosnia and Herzegovina but also in the region ${ }^{18}$. The current and not at all harmless security problem of the Balkan countries is migration, and the absence of an integrated European approach to solving this issue ${ }^{19}$. Despite all the above, there is a lack of a comprehensive scientific analysis of indicators that affect the state of national security in Serbia, which is another argument for the research that this article deals with. However, the scope of the issue and the wide variety of variables limit the ambition of the work to point to indicators, subjects and contribute to the rationalization and objectification of the approach to the issue of national security in Serbia.

16 Appearances by Albanian officials indicate that the idea of a "Greater Albania" is not a myth. For example, in the EU Parliament in 2018, a question was raised regarding the statements of Albanian officials on unification with Kosovo as part of the „Greater Albania” project. However, the response of the representatives of the European Commission was vague and did not condemn such tendencies. In general, the attitudes of the EU administration are very mild towards the Albanian aggressive actions, avoiding the identification of such speeches as negative, which only encourages Albanians to continue with such rhetoric. More at: European Parliament, Parliamentary questions, Subject: 'Greater Albania' and the unification of Kosovo and Albania, [28 XI 2018], https://www.europarl.europa.eu/doceo/ document/P-8-2018-005976_EN.html (17 I 2021).

17 B. Bashota, B. Dugolli, Kosovo-Serbia agreements between creative and destructive ambiguity, „Revista UNISCI / UNISCI Journal” 2019, No. 50, DOI: http://dx.doi.org/10.31439/ UNISCI-52.

18 D. Živojinović, S. Nedeljković, M. Krstić, (urednici), Dvadeset godina od Dejtonskog mirovnog sporazuma - trajni mir ili trajni izazovi?, Beograd 2016.

19 L.S. Pejanović, Uzroci migracija i izbeglička kriza na Balkanu i u Evropi, „CIVITAS” 2017, 7(1), p. $79-88$. 


\section{Contemporary approach to national security and forms of threats}

National Security is a comprehensive description of the state of absence of endangering the nation and its vital interests. The Boston Educational Journal in December 1919, understanding national security as a wide range of social phenomena in the country, stated that national security is not guaranteed but should be fought for, and there is no national security without the protection of all public interests relevant to the welfare of the nation ${ }^{20}$. The notion of national security was introduced into operational use at the end of World War II in the United States through an initiative to form a "national defense council," which created the National Security Council in $1947^{21}$. From then until today, the attitude towards national security issues has been marked by changes in international relations, weakening of relations between the political elite and citizens, changes in political culture, as well as partial loss of state sovereignty due to multilateralism and collective security ${ }^{22}$.

National security is determined based on natural and social elements of state power. Natural determinants (geography, resources, and population) refer to the population number and physical environment. Social determinants (economic, political, military, psychological, and informative), concern the way of a nations organize and the change their environment ${ }^{23}$. National security is a state's ability to independently or with other states or organizations protect society's solid values and interests from external and internal forms of threats and provide conditions for its development ${ }^{24}$. National security is part of a state's policy to create national and international political conditions that favorably affect the protection or expansion of vital national values towards existing or potential adversaries ${ }^{25}$.

National security is achieved through the functions of the national security system. The national security system has internal elements (police, security services, emergency organizations, private security, the judicial system, etc.) and external elements (army) and intelligence services ${ }^{26}$.

20 A.E. Winship (ed.), National security, „Journal of Education” 1919, Vol. 89, Issue 26, p. 722.

21 M. Neocleous, From Social to National Security: On the Fabrication of Economic Order, „Security Dialogue” 2006, Vol. 37, No. 3, p. 363-384.

22 T. McCormack, The British National Security Strategy: Security after Representation, „BJPIR” 2015, Vol. 17, p. 494-511, DOI: 10.1111/1467-856X.12052.

23 Ibidem.

24 Љ. Стајић, Р. Гаћиновић, Увод у студије безбедности, Београд 2007, p. 57.

25 D. Jablonsky, National power, [in:] eds. J.R. Cerami, J.F. Holcomb, Jr., U.S. Army war college guide to strategy, Carlisle 2001.

26 Г. Остојић, Д. Митровић, Савремено схватане националне безбедности, „Војно дело” 2017, No. 6, p. 107, DOI: 10.5937/vojdelo1706105O. 


\section{Endangering national security}

The essence of dealing with national security is analyzing possible threats, projections of the future situation, and planning measures for its improvement. Until the late 1970s, military threats were the core of security assessments, but during the 1980s, awareness of the use of non-military forms of security breaches rise up. An integrated analytical approach is most often used as a basis for assessing trends relevant to national security. It represents a synthesis of macro (international relations, social and geopolitical trends, economic and political trends, global effects on the international system) and micro (scenario according to individual issues and determinations of possible crises for a particular country) analysis with an elaboration of scenarios of possible crises and assessment of relevant trends for the national security ${ }^{27}$.

Beside we could notice that nation security (physical survival of a nation) could be recognized as a part of state security (state institutions, public administration, armed forces, etc.), some research support idea that approach of „Copenhagen School" could successfully broaden the concept of security through adding the concept of the societal security into security studies ${ }^{28}$. There are several approaches to national security analyzes. One of the dominant is the approach of the so-called - „Copenhagen School," which is based on existential threats, survival, confrontation, and competition ${ }^{29}$. Beside of some critical approach which consider non-universality of so called „Buzan's theory”, and it's applicability in mostly western cultural and civilization environment ${ }^{30}$, it is indisputable that "Copenhagen School," have strong influence on contemporary security science. Characteristically, this school of thought recognizes threats as the main content of the concept of security. Another group of authors suggests risk as to the central concept of security ${ }^{31}$. Simultaneously, the risk emphasizes the „conditions of possibility" in which the risk could turn into actual damage ${ }^{32}$. Three approaches to risk can be pointed out: 1) „Risk as governance” represents the transformation

27 A. Nils, Futures Studies and National Security: The Swedish Experience, „Cooperationand Conflict" 1981, XVI, p. 39-56.

28 H.H. Hama, State Security, Societal Security, and Human Security, „Jadavpur Journal of International Relations" 2017, 21(1), p. 1-19.

29 B. Buzan, O. Waever, J. de Wilde, Security: A New Framework for Analysis, London 1998.

30 J. Besenyö, Barry Buzan's Securitization Theory and the case of Iraqi Kurdishmilitary action against ISIS in 2014, „Journal of Security and Sustainability Issues” 2019, 8(3), p. 295-306. http://doi.org/10.9770/jssi.2019.8.3(1).

31 O. Corry, Securitisation and 'Riskification': Second-order security and the politics of climate change, „Millennium: Journal of International Studies” 2012, 40(2), p. 235-258.

32 A. Hammerstad, I. Boas, National security risks? Uncertainty, austerity and other logics of risk in the U.K. Government's National Security Strategy', „Cooperation and Conflict” 2015, Vol. 50(4), pp. 475-491, DOI: 10.1177/0010836714558637. 
of the concept of security from war and violence into governance and technology, from the sociological basis of governance; 2) „Global risk management," also transforming the approach, according to which risks are unpredictable, so risk management turns into control of uncertainty; 3) „Political analytical," is a management approach that develops methods for determining the probabilities and impacts of a particular risk ${ }^{33}$.

Today, there is no adopted uniform definition of security challenges, risks, and threats, but they are most often viewed as a degree of danger to the security. Endangering of a national security is observed through three stages: ${ }^{34}$

1) Challenge is a term that means a phenomenon or process that is possible and probable, comprehensively and value-indeterminate. If the adverse determination prevails, the challenge becomes a risk, and the probability of harmful influence gradually increases. A challenge is a condition in which the subject is subjected to a trial, where the situation may have a positive or negative epilogue.

2) Risk is the possibility of loss, injury, discomfort, damage, or destruction. Unlike challenges, risk has a negative connotation. Besides, the challenge exists or does not exist, and the risk is more or less likely.

3) Threat represents a clear intention to cause damage, inflict damage, injury, destruction, or punishment. In the broadest sense, a threat is a conscious intention to cause harm to a person, entity, property, or correct, to force an object to comply with imposed behavior.

Overall term for state of potential national insecurity is endangering. The endangering of national security is phenomena caused by human or natural factors whose duration and intensity cause or may lead to harmful consequences for the reference values and interests of the individual, society, state, and international community. Also, each value can be threatened by several different threats, but several different values can also threaten one type of threat.

The incorporated approach to political, economic, social, environmental aspects and military issues represents the unified security agenda of the modern approach to the analysis of national security and the framework for the projection of trends in its development. Keeping in mind the current change in the physiognomy of modern war as the supreme form of endangering and violating national security, which has visible deviation from the classical "Klauzovic's” theory of war, it is possible to speak of postmodern warfare ${ }^{35}$. Namely, modern conflicts dynamically combine conventional and unconventional methods, actions of state and non-state actors, means, and technologies with limited use of military power.

33 Ibidem.

34 Ibidem.

35 М. Митровић, Н. Николић, Хибридни рат - допринос дефинисағу кониепта, садржаја и модела деловаюа, Београд 2021 (in printing). 
Modern warfare, called hybrid warfare, has no goal to destruction but taking over the opponent and his capacities, which are engaged per the interests of the hybrid occupier. In short, hybrid warfare is a postmodern concept of low-intensity conflict, which nonlinearly and flexibly combines conventional and unconventional forms of action on the nation's comprehensive defense capabilities, to engage it by the interests of the aggressor, with limited use of force and whose protagonists may be different organizational entities (from state to terrorist groups) ${ }^{36}$.

The complexity of current geopolitical events, international relations, and the dynamic development of scientific thought and theory of understanding state and national security, modern forms of their threat, indicates the need for critical and constant observation. A specificity of Serbia is its historical and geopolitical position, the burden of recent conflicts, identity transformation, the level of development of political culture, international relations, etc. The factors that determine the state and national security of Serbia are complex, and it is necessary to approach them comprehensively. In the next part of the paper, within the framework provided by the scope of the article, a concise analysis of Serbia's attitude towards its own national security was performed.

\section{Current attitude of the Republic of Serbia towards national security}

The current National Security Strategy of the Republic of Serbia (NSS RS) was adopted in 2019 and represented the basis for other strategic documents in the field of national defense and security. The analysis of the NSS RS indicates an approach that starts from the macro to the micro-level of assessments and setting goals for the defense of national interests. It points to multipolarity and multilateralism in global international relations and the reduced possibility of direct conflicts between states due to solid integrative processes in politics and security. However, the existence of altered forms and characters of security threats is emphasized. Economic and cultural differences are recognized as the leading general conditions for security breaches. The primary forms of global security threats are regional and local conflicts, ethnic and religious extremism, terrorism, organized crime, a proliferation of weapons of mass destruction, illegal migration, hybrid threats, cyber threats, limited availability of natural resources, including water, food, energy and raw materials, as well as climate change and degradation of the natural environment, threaten the stability of individual countries and entire regions, as well as global security. The source of instability is the violation of the United Nations Charter and generally accepted norms of international law, espe-

$36 \quad$ Ibidem, s. 137. 
cially interference in sovereign state's internal affairs and the concept and practice of preventive and military interventionism. With the constant competition of great powers, all of the above represents the general framework of global security. The most likely causes of long-term global insecurity are international terrorism, organized crime, the strengthening of political and religious extremism, the migrant crisis, and mediation conflicts ${ }^{37}$.

Considering the situation in Southeast Europe, the NSS RS recognize as a primary potential sources of instability separatist aspirations, ethnic, religious, political extremism, economic and social problems, migration, organized crime, insufficient state institutions, and natural disasters. The Western Balkans are particularly burdened by the unresolved issues of the wars of the 1990s, based on which new states emerged, with the pressure of the legacy of the past, historical contradictions, regulation of minorities, resolving the issue of missing persons and war crimes prosecutions. Based on all the above, NSS RS consider that "The risks of outbreaks of wars and other armed conflicts in Southeast Europe, although reduced, have not been eliminated" 38 .

The separatist aspirations in the region are especially emphasized as a real threat. For the countries in the region, and especially for the Republic of Serbia, the

illegally unilaterally declared independence of the territory administratively covered by the Autonomous Province of Kosovo and Metohija (AP KaM), non-implementation of the Brussels Agreement on the principles of normalization of relations and slow establishment of democratic standards in KaM, disrespect fundamental human rights of the Serbian and other non-Albanian population, usurpation, and destruction of their property and cultural and historical heritage, as well as the strengthening of radical Islamism, is a source of long-term instability in the region. The recognition of the independence of that part of the Republic of Serbia by certain countries in the immediate vicinity and some countries in the world adversely affects the strengthening of confidence and cooperation measures and slows down the stabilization process in this area ${ }^{39}$.

As a positive impact on the state of national security of the Republic of Serbia, the document states that „Progress in the Republic of Serbia's accession to the European Union has a positive impact on its political, economic and social stability." The development of partnership cooperation between the Republic of Serbia and NATO, based on military neutrality and through the Partnership for Peace

37 Стратегија националне безбедности Републике Србије (Службени гласник РС, број 94, 27 XII 2019, p. 13-26), https://www.pravno-informacioni-sistem.rs/SlGlasnikPortal/viewdoc?uuid=8347b249-c036-4cd7-ba91-2b5ecdc035ec (10 I 2021). 
program, and the observer position in the Collective Security Treaty Organization (CSTO) contributes to the stability of the Republic of Serbia. For the further development of democracy, stability, and prosperity of the region, the Republic of Serbia needs to improve relations with the United States, the Russian Federation, the People's Republic of China, and other traditional partners' essential factors community ${ }^{40}$.

Indicators related to the autonomous province of KaM are recognized as the most significant factor endangering the national security of the Republic of Serbia: 1) Tendency of its permanent secession and development of negative security trends within it; 2) Conditioning the Republic of Serbia in the process of accession to the European Union by recognizing the forcible secession of its territory as a legitimate act; 3 ) Reduction of the international presence (UNMIK, KFOR, OSCE, etc.) which is the guarantor of the status of the AP KaM, and the efforts to form the armed forces of „Kosovo”, which is contrary to United Nations Security Council Resolution 1244. Also, radical Islamist core, illegal migrations, acts of terrorism, various forms of organized crime, economic and demographic development problems, the consequences of natural disasters, and high-tech crime are recognized as the causes of potential threats to the Republic of Serbia's national security ${ }^{41}$.

The Republic of Serbia, as a declared neutral state, relies on the development of its capacities for the protection of national security, with the development of cooperation with all partners with whom it has recognized mutual interests. The direct aggression, although not excluded, is very unlikely. As the main challenges, risks, and threats to national security NSS RS recognized: Separatist aspirations and illegally unilaterally declared the independence of the AP KaM; Armed insurrection with extremist core groups operating in the AP KaM; Terrorism; A proliferation of weapons of mass destruction; Ethnic and religious extremism supported from abroad; Intelligence activities through subversive propaganda activities aimed; Organized crime; Drug addiction; Illegal migration; Problems of economic and demographic development; Energy security; Pandemics; Unfinished demarcation with other ex-SFRY countries; Climate change and natural disasters; High-tech crime and endangerment of information and communication systems; Corruption; Abuse of new technologies and scientific achievements; Genetic engineering, medicine, meteorology, and other scientific fields misuses ${ }^{42}$.

Declared national values are freedom, independence, peace, security, democracy, the rule of law, social justice, human and minority rights and freedoms, equality and equality of citizens, tolerance, transparency, solidarity, patriotism,

\footnotetext{
$40 \quad$ Ibidem.

$41 \quad$ Ibidem, p. 16.

${ }^{42}$ Ibidem, p. 16-17.
} 


\begin{tabular}{|c|c|c|c|c|c|c|c|}
\hline \multirow{5}{*}{ 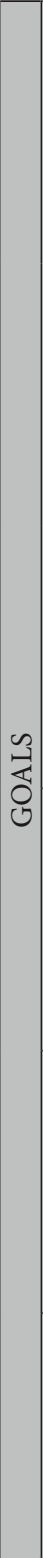 } & \multirow{2}{*}{ 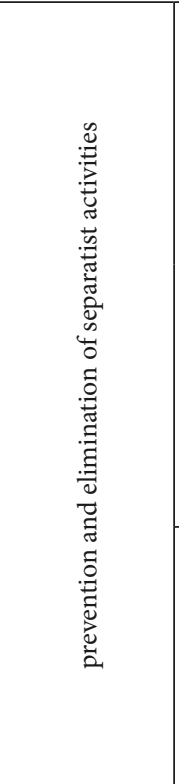 } & 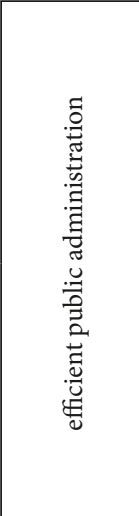 & 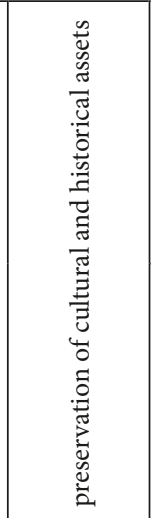 & 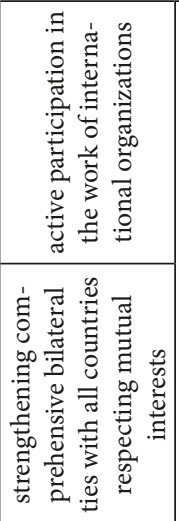 & \multirow{3}{*}{ 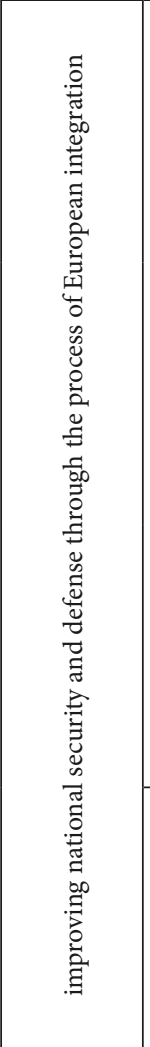 } & \multirow{2}{*}{ 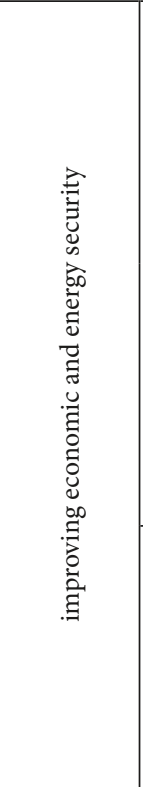 } & 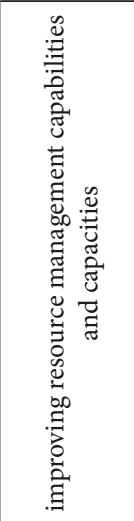 \\
\hline & & 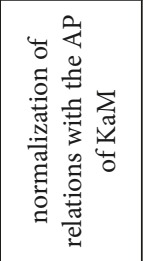 & 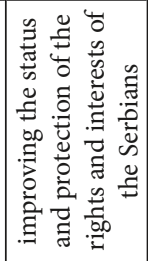 & 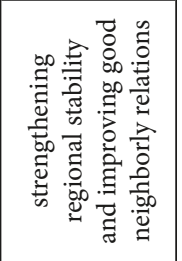 & & & 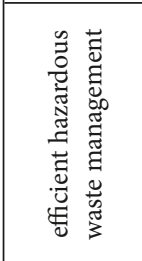 \\
\hline & 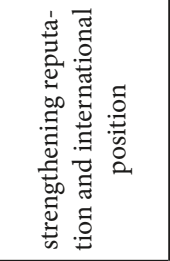 & 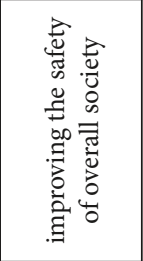 & 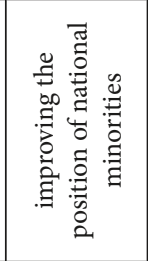 & 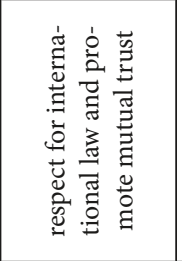 & & 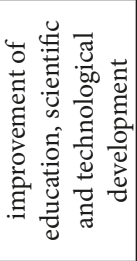 & 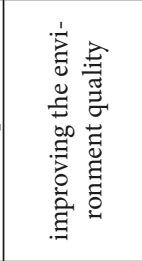 \\
\hline & 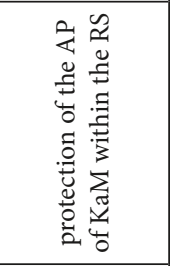 & 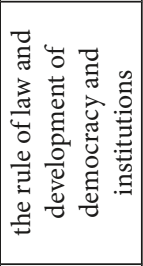 & 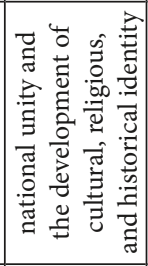 & 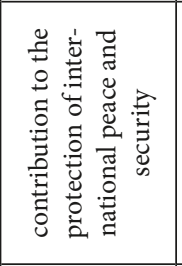 & 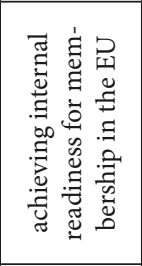 & 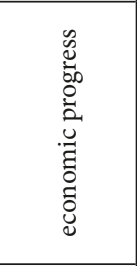 & 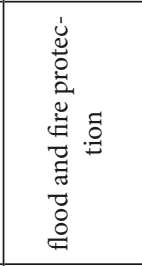 \\
\hline & 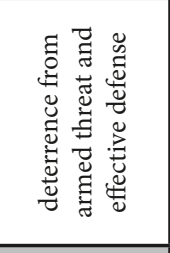 & 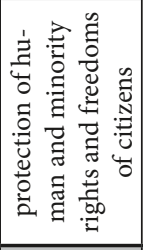 & 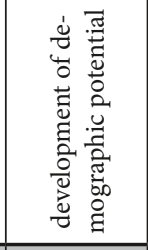 & 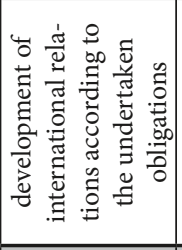 & 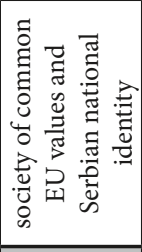 & 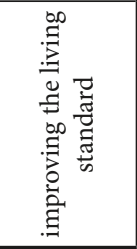 & 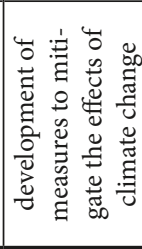 \\
\hline & 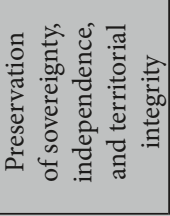 & 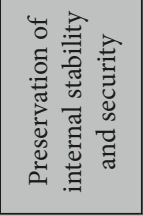 & 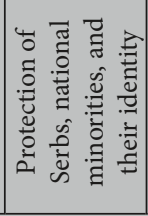 & 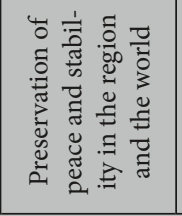 & 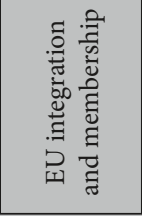 & 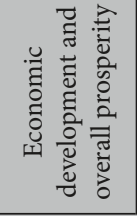 & 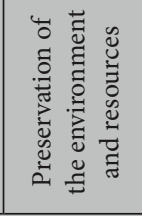 \\
\hline & & & & $\mathrm{LSH}$ & & & \\
\hline
\end{tabular}


and a healthy environment ${ }^{43}$. The national interests that protect national values are: preservation of sovereignty, independence, and territorial integrity; Preserving internal stability and security; Preserving the existence and protection of the Serbian people wherever they live, as well as national minorities and their cultural, religious and historical identity; Preserving peace and stability in the region and the world; European integration and membership in the European Union; Economic development and overall prosperity and preservation of the environment and resources of the Republic of Serbia ${ }^{44}$.

Within elaborating the stated interests, the NSS RS determines the goals and actions of preserving all the listed values. An overview of national interests and the goals they achieve is shown in Table 1 .

\section{Rationalization of the Serbia's national security situation}

The conditionality of the analysis of the content of the security concept changes within the limits of understanding and acceptability of social, cultural, and historical parameters of a particular time and space ${ }^{45}$. This position is the starting point for a framework critique of the current National Security Strategy of the Republic of Serbia. To clear understanding the present condition, it is necessary to approach the condition's genesis in the most general terms. In the modern era, the Republic of Serbia, exist as an independent state since 2006, when the Republic of Montenegro separated and became independent from the then state union $^{46}$. The genesis of the modern independence of the Republic of Serbia has a turbulent and historically complex structure. After the end of the First World War, Serbia, as a victorious power, generously invested its victims in creating a new joint state with an ambitious and inspired goal to unite all southern Slavs in the Western Balkans ${ }^{47}$. This state, later called Yugoslavia, marked the Serbian and other peoples of Southeast Europe during the twentieth century. After the end of the Second World War, Yugoslavia remained in the Soviet domain. But, conflict between two communist dictators, Tito in Yugoslavia and Stalin in the USSR, in 1948, make Yugoslavia set out on its path, approaching the West in part, with its own declared interpretation of applied communism - self-governing socialism $^{48}$. Until the fall of the Berlin Wall, Yugoslavia balanced between the

$43 \quad$ Ibidem, p. 17-18.

44 Ibidem, p. 18-24.

45 Hammerstad, Boas, op.cit., p. 477.

46 R.R. Cvetković Mrdaković, Međunarodni kontinuitet Srbije posle odvajanja od Crne Gore, „Međunarodni problemi” 2006, Vol. LVIII, br. 3, s. 326-346.

47 A.S. Trbovich, A Legal Geography of Yugoslavia's Disintegration, Oxford 2008.

48 M. Stevović, Sukob Jugoslavije sa Informbiroom, Lajkovac 2020. 
great powers, founding a movement of non-aligned states that primarily brought together third-world countries. With Tito's death and the end of the Cold War, Yugoslavia disintegrated in a bloody series of civil wars during the 1990s. Serbia, which brought its statehood to Yugoslavia, had a limited influence throughout its existence, constantly accused of domination, although most of the central state functions were held by members of other nation ${ }^{49}$. During Yugoslavia's existence, Serbia immersed its national identity in the structure of a higher state entity. Consequently, it is only with independence in the first decade of the 21st century that Serbia is strongly confronted with its state and national identity problems ${ }^{50}$. It can be said that national and state identity, national and political culture, value systems in modern Serbia are still maturing, dynamically pulsating, and insufficiently defined. Precisely this thesis can serve as a starting point for a critical review of Serbia's current National Security Strategy. The Republic of Serbia belongs to a set of post-communist states that have not yet developed a sustainable political culture that would guarantee society's long-term internal stable progress. Namely, the multi-party system was introduced by decree, and the state institutions did not develop a sufficient degree of independence and autonomy in their work. Thirty years since the official introduction of democracy, despite the declared and legally regulated norms and procedures in all branches of government, political practice indicates that the real power is on the side, at the moment the most potent political parties, and not on independent institutions. The system's essential stability and resilience are not enabled by the formal introduction of democracy but by the development of institutions and respect for the law. Research indicates that Serbia is under significant pressure from hybrid threats and that based on state stability indicators (corruption, rule of law, media freedom, etc.), it can be concluded that it will be in the future ${ }^{51}$.

From the perspective of the foreign policy approach, two national security priorities were emphasized: 1) the struggle to preserve KaM within the framework of state sovereignty and 2) integration into the EU. They are not officially mutually conditioned, but they have a solid iteration. Namely, the patrons of KaM's independence are the strongest countries in the West, and the United States is an undisguised leader in representing the interests of the self-proclaimed „Republic of Kosovo" 52 . In that way, Kosovo is in a significantly more favorable position,

49 Trbovich, op.cit.

50 M. Milenković, O očuvanju nacionalnog identiteta $i$ kulturne baštine u evropskim integracija$m a$, „Етноантрополошки проблеми” 2013, год. 8, св. 2, с. 454-470.

51 M. Mitrović, The Balkans and non-military security threats - quality comparative analyses of resilience capabilities regarding hybrid threats, „Security and Defence Quarterly” 2018, Vol. 5, No. 22, p. 20-45, DOI: https://doi.org/10.5604/01.3001.0012.7224.

52 М. Митровић, Потенцијални утицај интересних група на спољну политику САД: случај „Косово”, „Зборник матице српске за друштвене науке” 2017, br. 163, s. 413-428. 
which can be seen by ignoring and refusing to apply the obligations assumed by international agreements. At the same time, Kosovo does not suffer any sanctions due to this attitude. On the contrary, even aggressive actions, such as introducing product taxes, despite the formal declarative condemnation of Brussels and Washington, are tolerated and not sanctioned ${ }^{53}$. On the other hand, Russia and China provide proper support to Serbia in international institutions in terms of sovereignty over Kosovo. In international relations, establishing relations based on interests applies, which both Russia and China significantly implement. Namely, Russia supports Serbia in the OUN and takes the position that it will support any agreement that Serbia adopt. At the same time, whenever defending Russia and the Russian people on certain forms of independence, autonomy, or even succession, Russian officials use the opportunity to highlight the example of the Albanians in Kosovo as a positive practice of the people's right to secede ${ }^{54}$. Also, Russia is strongly acting in social networks and electronic media and supports organizations and parties in Serbia by applying an offensive approach in strategic communication, which directly affects national security. This enables it to significantly influence Serbia's public opinion through psychological, sociological, cultural, media, and religious-historical soft power instruments. Generally, Serbia is under strong influence of Russia's strategic communication (SC) acts, which could be recognized in overall implementation of SC determinants (propaganda, public diplomacy, lobbying, public opinion manipulation, subversive acts, etc. $)^{55}$. Based on its support to Serbia in the UN regarding Kosovo, China primarily uses public diplomacy's economic instruments, with a significant presence in infrastructure ventures, loans, and investments in the Serbian industry. It is essential to point out that China has become the owner of several vital components of national security infrastructure, such as the steel plant in Smederevo and the gold mine in Majdanpek. It is noticed that often, trade transactions are presented as aid and purchased products as donations. Such performances are significantly used in promotional spheres and in creating a positive public opinion. Simultaneously, the increase in industrial production in new Chinese factories has caused a drastic deterioration of the environment, primarily due to Serbia's outdated and dirty technologies ${ }^{56}$.

53 Radio Free Europe, Kosovo Spurns EU, U.S. Calls To Lift Heavy Tax On Serbian Imports [30 XI 2018], https://www.rferl.org/a/kosovo-spurns-eu-us-calls-lift-tariff-serbian-imports-normalization-sovereigty-talks-haradinaj/29629531.html (20 I 2021).

54 B. Barlovac, Putin Says Kosovo Precedent Justifies Crimea Secession, BalkanInsight [18 III 2014], https://balkaninsight.com/2014/03/18/crimea-secession-just-like-kosovo-putin/ (10 I 2021).

55 М. Митровић, Детерминанте стратешке комуникације од значаја за националну одбрану и безбедност, „Зборник матице српске за друштвене науке” 2019, LXX, Бр. 170, c. 179-194, https: doi.org/10.2298/ZMSDN1970179M.

56 S. Shehadi, How China is enabling an environmental crisis in the Balkans [29 I 2021], CEE and CIS, https://investmentmonitor.ai/extraction/how-china-is-enabling-an-environmental-crisis-in-the-balkans (30 I 2021). 
Regarding European integration, according to the report for 2020, in terms of foreign policy, the harmonization of the EU and the Republic of Serbia is observed through regional cooperation, normalization of relations with „Kosovo," and general harmonization with the Common Foreign and Security Policy of the $\mathrm{EU}^{57}$. Joining the European Union is one of the declared strategic goals of importance for Serbia's national security. Since 2006, the Republic of Serbia has been implementing European integration process. The general rules on association are fulfilled with additional chapter under number 35 , „other," which refers to the normalization of relations between Belgrade and Pristina. In the period from 2015 to October 2020, the Republic of Serbia opened a total of eighteen negotiating chapters and conditionally closed two (25 - „science and research” and 26 - „education and culture"). During 2020, Serbia did not open or close any negotiating chapters. On the issue of normalizing relations with "Kosovo" during 2020, two rounds of negotiations were held and meetings at the expert level. The EU believes that „Serbia should make further substantial efforts and contribute to reaching a comprehensive, legally binding agreement with Kosovo. Such an agreement is urgent and crucial so that both Kosovo and Serbia can progress on their European path." 58

The European Union rely on that Serbia is ,in line with $60 \%$ of the positions of the EU's Common Foreign and Security Policy in 2019 and should intensify efforts to gradually align its foreign and security policy with the EU's common policy in the period before accession. ${ }^{59}$. Simultaneously, the EU indirectly criticizes Serbia for its specialties with, above all, Russia and China. These ties are particularly subject to critical observation not only in terms of foreign policy coherence, which is predominantly focused on the support of these countries to Serbia's position in negotiations with Kosovo but also in the economy (protection of competitiveness and transparency and the political aspect of environmental protection and harmful technologies). It can be said that the process of European integration of Serbia is stagnant, both because of specific internal slow reform processes and because of many existing problems in the EU. Namely, solid political turbulence, the British Brexit, the slowdown in economic growth, the crisis in transatlantic relations, problems in relations with Russia, concerns about China's growing influence in Europe, among other things, affect the general reluctance to further enlargement $t^{60}$. The process is in crisis, and European institutions have an

57 Делагација Европске уније у Републици Србији, Годишњи извештај о напретку европских интергаиија Републике Србије [16 III 2021], http://europa.rs/godisnji-izvestaj-o-srbiji-2020/\# (20 III 2021).

S. Stojanović, J. Šaranović, EU strategy for Western Balkans and perspective of further Europeization of the Balkans, [in:] ed. B. Forca, The scope of the strategy of the European Union for the Western Balkans, Belgrade 2020, p. 99-117. 
increasingly loud critical view of Belgrade's authorities. According to them, the EP report sharply criticizes the situation in the media, the political climate, and unresolved scandals, which, according to them, violate Serbia's internal stability and the actual degree of harmonization with general European norms, is worrying ${ }^{61,62}$. In economic terms, the EU is the most significant donor and patron of Serbia, but this is not significantly promoted in media and present in public opinion ${ }^{63}$.

The Republic of Serbia has declared military neutrality, which international acts have not confirmed. Simultaneously, Serbia has good changeable relations with all its neighbors, which gained statehood with Yugoslavia's disintegration, which are not particularly developing. Namely, in all former Yugoslavia countries, it is noticeable that even 25 years after the war conflicts, political elites often use the revival of nationalism as an effective instrument of daily politics and preserving their political privileges. Such turbulent situations are shaking the region, the neighborhood, and even Serbia ${ }^{64}$.

\section{Conclusion}

Modern times require an approach to social issues that align with the current environment and rationally considered trends in its development. Therefore, the issue of national security should be a reflection of a natural and possible response to the manifested forms and contents of its endangerment. Simultaneously, it is necessary to take a critical attitude towards one's problems and determine the proposed measures rationally and energetically. The Republic of Serbia is in a particular position, at the crossroads of conflicting geopolitical interests, with a complex historical legacy and an unfinished political, economic, cultural, and social transformation from social to neoliberal capitalism. In the case of Serbia, national security must be based on sincere, strong, and complete regeneration of the nation in terms of its knowledge, a radical change of culture and development of a new value system, establishment of a genuinely democratic society, turning to the future and achievable and practical goals. Building state security

61 EWB, Skoro 400 amandmana na izveštaj EP o Srbiji: Poslanici za strožu kritiku stanja u zemlji [6 I 2021], https://europeanwesternbalkans.rs/skoro-400-amandmana-na-izvestaj-ep-o-srbiji-poslanici-za-strozu-kritiku-stanja-u-zemlji/ (10 I 2021).

62 N1 Belgrade, AFET adopts report on Serbia calling on it to resolve affairs [24 II 2021], https:// rs.n1info.com/english/news/afet-adopts-report-on-serbia-calling-on-it-to-resolve-affairs/ (25 II 2021).

63 Delegacija EU u RS, Pomoć EU Republici Srbiji [17 III 2021], https://europa.rs/pomoc-eu-republici-srbiji/ (18 III 2021).

64 I. Petrović, M. Radoman, Vrednosne orijentacije političke elite: Patrijarhalnost, autoritarnost i nacionalizam, [in:] ed. M. Lazić, Politička elita u srbiji u periodu konsolidacije kapitalističkog poretka, Beograd, p. 143-178. 
needs to be given to internal aspects, consolidation of the nation, and orientation towards prosperous and socially balanced goals. Namely, a strong and internally consolidated state is significantly more resistant to all forms of endangering national security. From that point of view, it is necessary to wholly and energetically empower institutions, apply the law and identify and sanction internal negative phenomena. It is necessary to comprehensively promote fundamental cultural values with a clear identification of negative phenomena and stigmatization and condemnation. It is necessary to involve a moral and ethical understanding of the mistakes and crimes committed by individuals, which will enable the homogenization of a positive and stable national identity. The cohesion of the nation based on stable foundations enables resistance to hybrid threats and subversive actions.

The security interest towards neighbors can be focused on the continuous development of good neighborly relations, identification and condemnation of crimes, reconciliation, and a shared focus on the future, following the common interests. It is necessary to mark the capacities and strength to rationalize the past's attitude and turn to the future. There is an opportunity to persevere in developing relations with Prishtina for all citizens' benefit, the objectification and disclosure of all cases of war crimes, and the identification and condemnation of perpetrators. There are significant space and capacity to develop relations with decision-makers and forces that have a real impact on processes to establish relations with Albanians in Kosovo based on common regional interests and prosperity while respecting diversity and turning to life's content issues, not political populism.

The influence of regional and global powers, as well as Serbia's foreign policy aspiration and orientation have the significant implications on the issue of national security of the Republic of Serbia ${ }^{65}$. One of the priorities is to take radical and truthful measures in order to meet all EU standards as soon as possible. Namely, although the EU has its problems and that the continuation of negotiations and accession is uncertain, it is necessary to adopt the rule of law, social welfare, and other living conditions closest to European standards. For Serbia is more important that EU „enter” with its values in Serbia culture, identity and social habits, than formally getting position in EU institutions. By achieving better general living conditions for citizens, Serbia will also help create a solid national identity and strengthen national security.

As a general, overall approach, it is necessary to rationalize relations with all the great powers and recognize mutual interests. At the same time, it is necessary to develop relations based on the reciprocity of activities, primarily cultural,

65 M. Mitrovic, Assessments and foreign policy implementation of the national security of Republic of Serbia, „Security and Defence Quarterly” 2021, Vol. 34, No. 2, p. 7-19, DOI: 10.35467/sdq/ 135592. 
scientific, and cooperation in defense and security. A coordinated approach with a clear and sober attitude towards all global and regional entities that show interest and action in the Balkans (Russia, China, USA, Germany, Turkey, etc.) enables clear and concrete foreign policy action directions. Simultaneously, it is necessary to approach the assessments without favoring any subject because this leads to classification, the polarization of the internal public, and violation of the nation's cohesion, which significantly affects national security. As a general conclusion, the need to redefine the approach to creating national security emphasize, that the starting point for accomplishment National Security of Republic of Serbia is internal stability (micro-level), which can be influenced. Simultaneously, the geopolitical situation and relations (macro-level) represent a respected, but difficult or almost impossible framework to make an impact.

\section{Abstract \\ Miroslav Mitrovic \\ Serbia's National Security Strategy - from where, through what and where to go}

The National Security Strategy is one of the state's critical documents, which sublimates the knowledge of the security environment, possible forms of endangerment, and the proposed guidelines for ensuring the security of a nation. Dynamic processes in the geopolitical global, and regional environment, globalization of forms and content of possible security breaches, continuous arms race, and the dominant changed hybrid physiognomy of war are dominant vectors of influence on a national security strategy of every nation. In 2019, the Republic of Serbia adopted its recent National Security Strategy. The paper analyzes the declared foreign policy determinants of Serbia's national security strategies, intending to critically oppose them with current threats to Serbia's s national security. Based on the comparative method and analysis of current documents, with respecting the political and economic reality, the paper provokes the proposed priorities with possible development trends while respecting internal and external entities' influence on developing the national security system and state of the Republic of Serbia. The paper critically exploring the declared determinants of foreign policy in Serbia's national security strategies by means of analysis of current documents and comparative methods.

Keywords: national security, Republic of Serbia, soft power, strategic communication, national identity 


\section{References}

Baltes, M., Causes and Consequences of the Syrian Civil War, Senior Theses, University of South Carolina, 2016, https://scholarcommons.sc.edu/senior_theses/105.

Barlovac, B., Putin Says Kosovo Precedent Justifies Crimea Secession, 18 III 2014, https://balkaninsight.com/2014/03/18/crimea-secession-just-like-kosovoputin/.

Bashota, B. Dugolli, B., Kosovo-Serbia agreements between creative and destructive ambiguity, „Revista UNISCI/UNISCI Journal” 2019, No. 50, http://dx.doi. org/10.31439/UNISCI.

Besenyö, J., Barry Buzan's Securitization Theory and the case of Iraqi Kurdish military action against ISIS in 2014, „Journal of Security and Sustainability Issues” 2019, 8(3), https://doi.org/10.9770/jssi.2019.8.3(1).

Buzan, B., Waever, O., de Wilde, J., Security: A New Framework for Analysis, London 1998.

Cemgil, C., The international order and the persistence of 'violent extremism' in the Islamic world, „Philosophy and Social Criticism” 2017, Vol. 43(4-5), https:// doi.org/10.1177/0191453716682371.

Colgan, J., Fueling the Fire: Pathways from Oil to War, „International Security” 2013, No. 38(2).

Corry, O., Securitisation and 'Riskification': Second-order security and the politics of climate change, „Millennium. Journal of International Studies” 2012, 40(2).

Cvetković Mrdaković, R.R., Međunarodni kontinuitet Srbije posle odvajanja od Crne Gore, „Međunarodni problemi” 2006, Vol. LVIII, br. 3.

Delegacija EU u RS, Pomoć EU Republici Srbiji, 17 III 2021, https://europa.rs/ pomoc-eu-republici-srbiji/.

Delagacija Evropske unije u Republici Srbiji, Godišnjiizveštaj o napretku evropskih intergacija Repu, 16 III 2021, http://europa.rs/godisnji-izvestaj-o-srbiji-2020/\#.

Dennis, R., Dennis, K., Separatism, [in:] The Wiley Blackwell Encyclopedia of Race, Ethnicity, and Nationalism, (online), 2015, https://10.1002/9781118663202. wberen192.

Dvadeset godina od Dejtonskog mirovnog sporazuma - trajni mir ili trajni izazovi?, eds. Živojinović, D., Nedeljković, S., Krstić, M., Beograd 2016.

European Parliament, Parliamentary questions, Subject: 'Greater Albania' and the unification of Kosovo and Albania, 28 XI 2018, https://www.europarl.europa. eu/doceo/document/P-8-2018-005976_EN.html.

EWB, Skoro 400 amandmana na izveštaj EP o Srbiji: Poslanici za strožu kritiku stanja u zemlji, 6 I 2021, https://europeanwesternbalkans.rs/skoro-400-amandmana-na-izvestaj-ep-o-srbiji-poslanici-za-strozu-kritiku-stanja-u-zemlji. 
Hama, H.H., State Security, Societal Security, and Human Security, „Jadavpur Journal of International Relations" 2017, 21(1).

Hammerstad A., Boas, I., National security risks? Uncertainty, austerity and other logics of risk in the U.K. government's National Security Strategy, „Cooperation and Conflict" 2015, Vol. 50(4), https://doi.org/10.1177/0010836714558637.

Jablonsky, D., National power, [in:] U.S. Army war college guide to strategy, Cerami, J.R., Holcomb, J.F., Jr. (eds.), Carlisle 2001.

Jevtić, D., Talijan, M., Dumić, A., Geopolitičke promene i prekompozicije u globalnim odnosima, „Vojno delo” 2018, Vol. 70, br. 2, https://doi.org/10.5937/ vojdelo1802025J.

Lazić, M. (ed.), Politička elita u srbiji u periodu konsolidacije kapitalističkog poret$k a$, Institut za sociološka istraživanja Filozofskog fakulteta, Beograd.

McCormack, T., The British National Security Strategy: Security after Representation, „BJPIR” 2015, Vol. 17, https://doi.org/10.1111/1467-856X.12052.

Matthijs, M., Lessons and learnings from a decade of EU crises, „Journal of European Public Policy" 2020, 27(8), https://doi.org/10.1080/13501763.2020.1787 489.

Mirahmadi, H., Building Resilience against Violent Extremism: A Community - Based Approach, „ANNALS AAPSS”, 2016, No. 668, https://doi. org/10.1177/0002716216671303.

Milenković, M., O očuvanju nacionalnog identiteta i kulturnebaštine u evropskim integracijama, „Etnoantropološki problemi” 2013, god. 8. sv. 2.

Mitrovic, M., Assessments and foreign policy implementation of the national security of Republic of Serbia, „Security and Defence Quarterly” 2021, Vol. 34, No. 2, https://doi.org/10.35467/sdq/135592.

Mitrović, M., Determinante strateške komunikacije od značaja za nacionalnuodbranu i bezbednost, „Zbornik matice srpske za društvene nauke” 2019, LXX, br. 170, https://doi.org/10.2298/ZMSDN1970179M.

Mitrovic, M., Influence of global security environment on collective security and defence science, „Security and Defence Quarterly” 2019, Vol. 24, No. 2, https:// doi.org/10.35467/sdq/106088.

Mitrović, M., Nikolić, N., Hibridni rat - doprinos definisanju koncepta, sadržaja i modela delovanja, Beograd 2021 (in printing).

Mitrović, M., Potencijalni uticaj interesnih grupa na spoljnu politiku SAD: slučaj „Kosovo”, „Zbornik matice srpske za društvene nauke” 2017, br. 163.

Mitrovic, M., Savremeni izazovi upravljanja nacionalnom bezbednošću u hibridnom bezbednosnom okruženju, „Zbornik radova Međunarodne naučne konferencije EMAN 2017", Ljubljana.

Mitrović, M., The Balkans and non-military security threats - quality comparative analyses of resilience capabilities regarding hybrid threats, „Security and Defence Quarterly” 2018, Vol. 5, No. 22, https://doi.org/10.5604/01.3001.0012.7224. 
Mijalković, S., Milošević, G., Korelacija ekonomske, korporativne i nacionalne bezbednosti, „Megatrend revija” 2011, Vol. 8 (2).

N1 Belgrade, AFET adopts report on Serbia calling on it to resolve affairs, 24 II 2021, https://rs.n1 info.com/english/news/afet-adopts-report-on-serbia-calling-on-it-to-resolve-affairs/.

Neocleous, M., From Social to National Security: On the Fabrication of Economic Order, „Security Dialogue” 2006, Vol. 37, No. 3.

Nils, A., Futures Studies and National Security: The Swedish Experience, „Cooperation and Conflict" 1981, XVI.

Ostojić, G., Mitrović, D., Savremeno shvatanje nacionalne bezbednosti, „Vojno delo" 2017, No. 6, https://doi.org/10.5937/vojdelo1706105O.

Petrović, I., Radoman, M., Vrednosne orijentacije političke elite: Patrijarhalnost, autoritarnost i nacionalizam, [in:] Politička elita u srbiji u periodu konsolidacije kapitalističkog poretka, Lazić M. (ed.), Institut za sociološka istraživanja Filozofskog fakulteta, Beograd.

Phahlamohlaka J., Globalisation, and national security issues for the state: implications for national ICT policies, [in:] Social Dimensions of Information and Communication Technology Policy, Avgerou, C., Smith, M. L., van den Besselaar P. (eds.), IFIP Processing, Vol. 282, Boston 2008.

Pejanović, L.S., Uzroci migracija i izbeglička kriza na Balkanu i u Evropi, „Civitas” 2017, 7(1).

Radio Free Europe, Kosovo Spurns EU, U.S. Calls To Lift Heavy Tax On Serbian Imports, 30 XI 2018, https://www.rferl.org/a/kosovo-spurns-eu-us-calls-lifttariff-serbian-imports-normalization-sovereigty-talks-haradinaj/29629531. html.

Ripsman, N.M., Paul, T.V., Globalization and the National Security State, Oxford 2010.

Shehadi, S., How China is enabling an environmental crisis in the Balkans, 29 I 2021, CEE and CIS, https://investmentmonitor.ai/extraction/how-china-isenabling-an-environmental-crisis-in-the-balkans.

Stephen, L.F., Pezard, S., Radin, A., Chandler, N., Crane, K., Szayna, T.S., Russia and the West After the Ukrainian Crisis: European Vulnerabilities to Russian Pressures, Santa Monica 2017.

Stajić, L., Gaćinowić, R., Uwod u studije bezbednosti, Beograd 2007.

Stevović, M., Sukob Jugoslavije sa Informbiroom, Lajkovac 2020.

Stojanović, S., Šaranović, J., EU strategy for Western Balkans and perspective offurther Europeization of the Balkans, [in:] The scope of the strategy of the European Union for the Western Balkans, Forca B. (ed.), Belgrade 2020.

Strategija nacionalne bezbednosti Republike Srbije, „Službeni glasnik RS”, br. 94, 27 XII 2019, https://www.pravno-informacioni-sistem.rs/SlGlasnikPortal/ viewdoc?uuid=8347b249-c036-4cd7-ba91-2b5ecdc035ec. 
Teofilović, B., Teofilović, T., Teofilović, N., Sprega terorizma i organizovanog kriminala kao bezbednosni rizik, „Pravne teme” 2016, Godina 4, Broj 8.

Trbovich, A.S., A Legal Geography of Yugoslavia's Disintegration, Oxford 2008.

Winship, A.E., National security, „Journal of Education” 1919, Vol. 89, issue 26.

Miroslav Mitrović - dr bezpieczeństwa, adiunkt w Zakładzie Studiów Strategicznych w Instytucie Badań Strategicznych Uniwersytetu Obrony w Belgradzie. ORCID: 0000-0001-7541-8565 